\title{
Equipment for neonatal resuscitation in a middle-income country: a national survey in Vietnam
}

Daniele Trevisanuto ${ }^{1,2^{*}}$, Francesco Cavallin ${ }^{3}$, Gaston Arnolda ${ }^{4,5}$, Tran Dinh Chien ${ }^{4}$, Ornella Lincetto ${ }^{6}$, Ngo Minh Xuan ${ }^{7,8}$, Nguyen Viet Tien ${ }^{9}$, Nguyen Thi Xuan Hoi ${ }^{4}$ and Luciano Moccia ${ }^{2,4}$

\begin{abstract}
Background: Interventions to improve neonatal resuscitation are considered a priority for reducing neonatal mortality. In addition to training programs for health caregivers, the availability of adequate equipment in all delivery settings is crucial. In this study, we assessed the availability of equipment for neonatal resuscitation in a large sample of delivery rooms in Vietnam, exploring regional differences.

Methods: In 2012, a structured questionnaire on 2011 neonatal resuscitation practice was sent to the heads of 187 health facilities, representing the three levels of hospital-based maternity services in eight administrative regions in Vietnam, allowing national and regional estimates to be calculated.

Results: Overall the response rate was an $85.7 \%$ (160/187 hospitals). There was a limited availability of equipment considered as "essential" in the surveyed centres: stethoscopes (68.0 \%; 95 \% Cl: 60.3-75.7), clock (50.3 \%; 42.0-58.7), clothes (29.5\%; (22.0-36.9), head covering (12.3\%; 7.2-17.4). The percentage of centres equipped with polyethylene bags $(2.2 \% ; 0.0-4.6)$, pulse oximeter $(9.4 \% ; 5.2-13.6)$ and room air source $(1.9 \% ; 0.1-3.6)$ was very low.

Conclusion: Adequate equipment for neonatal resuscitation was not available in a considerable proportion of hospitals in Vietnam. This problem was more relevant in some regions. The assessment strategy used in this study could be useful for organizing the procurement and distribution of supplies and equipment in other low and/or middle resource settings.
\end{abstract}

Keywords: Equipment, Middle-income country, Neonatal resuscitation, Survey, Vietnam

\section{Background}

Worldwide each year about 6.6 million children under 5 years of age die and of these $44 \%$ are newborns. Intrapartum-related events, previously called "birth asphyxia", account for a quarter of neonatal deaths and almost all of them (99\%) occur in low-middle income countries [1].

Interventions to improve neonatal resuscitation are an essential part of any strategy to reduce neonatal mortality. Basic neonatal resuscitation and care in the so-called golden minute after birth may decrease neonatal mortality

\footnotetext{
* Correspondence: daniele.trevisanuto@gmail.com

${ }^{1}$ Women's and Children's Health Department, Medical School, University of Padua, Azienda Ospedaliera di Padova, Via Giustiniani, 3, 35128 Padua, Italy

${ }^{2}$ Amici della Neonatologia Trentina (ANT), Trento, Italy

Full list of author information is available at the end of the article
}

in low-resource settings and it is estimated to reduce fullterm infant deaths by up to $30 \%$ [2]. In addition to training programs for providers involved in the management of the neonates at birth, the availability of adequate equipment in all delivery settings is crucial. A recent review of data from 6 African countries showed that the percentage of birthing facilities with equipment for neonatal respiratory support ranged from 8 to $22 \%$ [2]. Simplified algorithms and lists of essential equipment for neonatal resuscitation at first referral level and higher in low-resource settings are recommended by international institutions such as World Health Organization (WHO) and American Academy of Pediatrics (AAP) [3, 4]. According to the WHO and the AAP "Helping Babies Breathe" program the list of essential equipment should include gloves, towels/ 
cloths, head covering, scissors, ties, suction device, ventilation device, stethoscope and timer [4].

South-East Asia is the regional area with the highest proportion of under-five mortality attributable to neonatal causes [5]. As Vietnam has implemented many initiatives and humanitarian plans in recent years [6], it is widely seen as a model among middle-income countries for the significant improvements in economy and health status. However, important challenges, such as the reduction of preventable neonatal mortality [5-7], and the disparity between different geographical and socio-economic regions [8-12], remain to be addressed.

In a previous study, we evaluated consistency of resuscitation practices and adherence to the international guidelines for neonatal resuscitation in a large representative sample of hospitals in Vietnam [13]. The present study reports data regarding the equipment available for neonatal resuscitation in the same sample of Vietnamese delivery rooms (DR), exploring regional differences.

\section{Methods}

\section{Participants and evaluation instrument}

In 2012, we conducted a survey of DR management among hospital based-obstetric and neonatal services in Vietnam [13]. The survey was performed using a structured questionnaire regarding DR practices in the domains of neonatal resuscitation (first part) and the equipment available at the centre (second part). (Additional File 1) The questions included multiple choices, brief responses, and yes/no questions. The questions all referred to the period 1 January to 31 December 2011.

Details of the survey have been previously published [13]. Briefly, 187 hospitals were chosen among the 610 hospitals with $\geq 500$ births in 2010 by (i) a census of all 6 central hospitals and all 72 provincial hospitals and (ii) a $20 \%$ sample survey of 532 district hospitals $(n=109)$ with $\geq 500$ births in 2011. The district hospitals were chosen from within each of the eight administrative regions commonly used for reporting purposes by the Government of Vietnam (Fig. 1), with each region restricted to providing $20 \%$ of the district hospitals in its catchment, following a stratified random sample with proportional allocation approach.

In this article, we report data referred to the second part (equipment) of the questionnaire. We considered the equipment as a) essential (included in the list of HBB algorithm) and b) advanced (recommended by the 2010 International Liaison Committee on Resuscitation (ILCOR) guidance and by the American Heart Association (AHA) $[14,15]$.

\section{Statistics}

The design of the sample survey has been described elsewhere [13]. In the present paper, all estimates are the

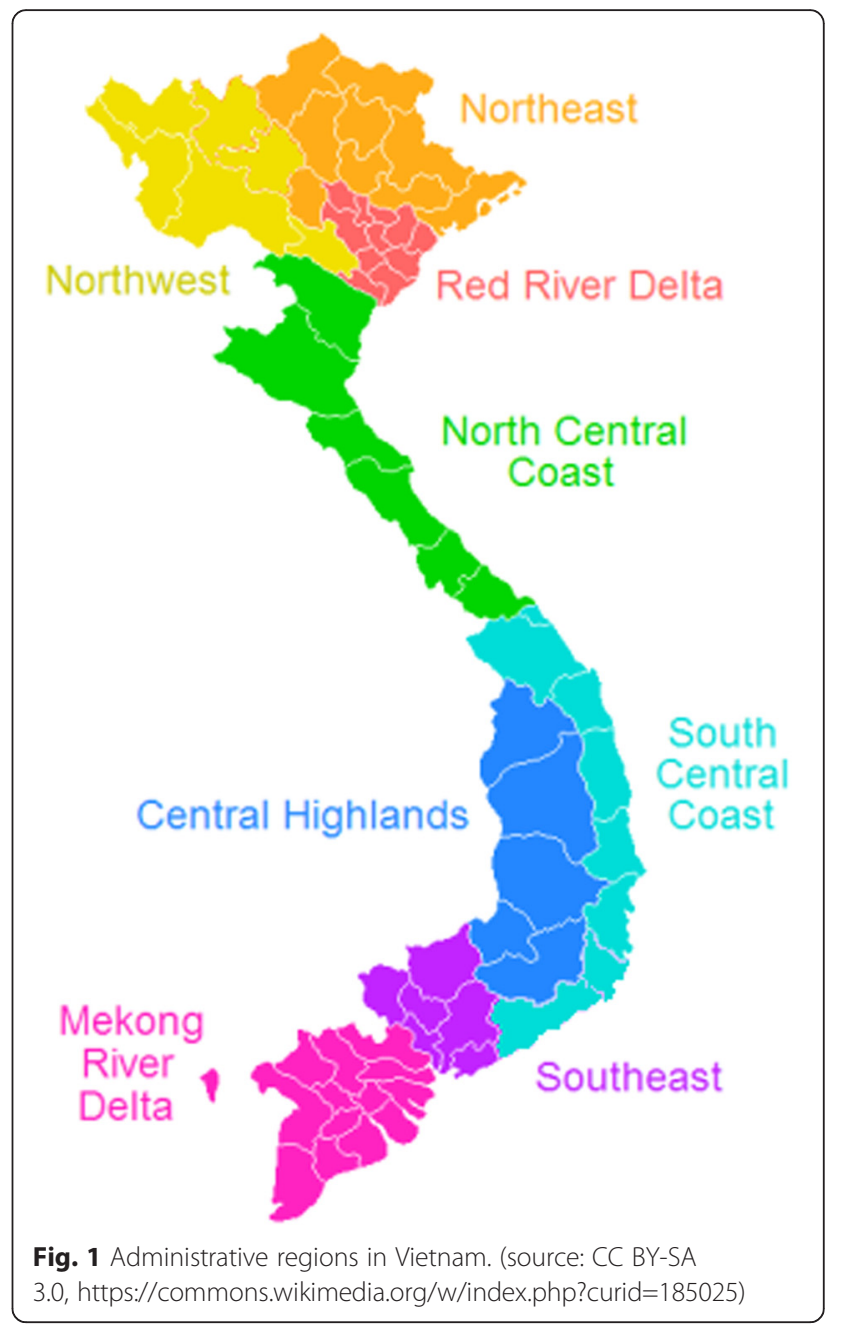

weighted aggregate of central, provincial and district level estimates after reweighting for sampling fraction, for district hospitals only, and nonresponse, for all three levels. No survey respondents failed to answer questions regarding equipment, therefore no additional reweighting for missing data was needed. National estimates and

Table 1 Number of participants according to hospital level and administrative region

\begin{tabular}{llllll}
\hline & & Central & Provincial & District & Total \\
\hline Northern VN & Red & 1 & 12 & 14 & 27 \\
& North central & 2 & 5 & 15 & 22 \\
& North east & 1 & 13 & 12 & 26 \\
& North west & 0 & 4 & 6 & 10 \\
Southern VN & Central highlands & 0 & 6 & 8 & 12 \\
& South central & 0 & 7 & 9 & 16 \\
& South eastern & 1 & 5 & 11 & 17 \\
& Mekong & 1 & 13 & 16 & 30 \\
& Total & 6 & 63 & 91 & 160 \\
\hline
\end{tabular}


Table 2 Essential equipment

\begin{tabular}{|c|c|c|c|c|c|c|c|c|c|}
\hline \multicolumn{2}{|l|}{ ESTIMATES } & \multicolumn{4}{|l|}{ Northern VN } & \multicolumn{4}{|l|}{ Southern VN } \\
\hline & Overall (n. 160) & $\operatorname{Red}($ n. 27) & North central (n. 22) & North east (n. 26) & North west (n. 10) & $\begin{array}{l}\text { Central highlands } \\
\text { (n. 12) }\end{array}$ & $\begin{array}{l}\text { South central } \\
\text { (n. 16) }\end{array}$ & $\begin{array}{l}\text { South eastern } \\
\text { (n. 17) }\end{array}$ & Mekong (n. 30) \\
\hline Scissors & $99.0(97.7-100.0)$ & $98.8(97.9-99.7)$ & $100.0(100.0-100.0)$ & $100.0(100.0-100.0)$ & $85.4(61.3-100.0)$ & $100.0(100.0-100.0)$ & $100.0(100.0-100.0)$ & $100.0(100.0-100.0)$ & $100.0(100.0-100.0)$ \\
\hline Suction device & $97.2(94.5-99.9)$ & $100.0(100.0-100.0)$ & $100.0(100.0-100.0)$ & $100.0(100.0-100.0)$ & $70.8(40.2-100.0)$ & $100.0(100.0-100.0)$ & $97.9(96.1-99.7)$ & $100.0(100.0-100.0)$ & $94.5(84.9-100.0)$ \\
\hline Gloves & 95.1 (91.6-98.6) & $92.8(82.2-100.0)$ & $92.6(81.9-100.0)$ & 98.8 (97.8-99.8) & $100.0(100.0-100.0)$ & $100.0(100.0-100.0)$ & $88.4(72.2-100.0)$ & $98.5(97.2-99.7)$ & $94.5(84.9-100.0)$ \\
\hline Ties & 89.5 (84.5-94.5) & 85.5 (71.2-99.9) & $79.1(62.1-96.2)$ & $97.6(96.1-99.1)$ & $70.8(40.3-100.0)$ & $89.0(70.3-100.0)$ & $97.9(96.1-99.7)$ & $100.0(100.0-100.0)$ & $89.0(75.9-100.0)$ \\
\hline Face mask & $84.2(78.0-90.3)$ & $84.3(69.9-98.7)$ & $81.8(64.7-98.8)$ & 71.0 (50.4-91.6) & $50.0(17.6-82.4)$ & $89.0(70.3-100.0)$ & $100.0(100.0-100.0)$ & $83.5(64.3-100.0)$ & $94.5(84.9-100.0)$ \\
\hline Stethoscope & $68.0(60.3-75.7)$ & $75.9(59.0-92.7)$ & $82.7(68.1-97.3)$ & $90.7(78.6-100.0)$ & $53.1(20.7-85.6)$ & $25.0(0.5-49.5)$ & $57.9(32.3-83.5)$ & $66.9(43.0-90.8)$ & $61.8(42.6-81.1)$ \\
\hline Clock & $50.3(42.0-58.7)$ & $59.2(39.4-79.0)$ & $41.8(20.9-62.7)$ & $56.9(35.4-78.4)$ & $20.8(0.0-45.2)$ & $22.1(0.0-46.6)$ & $46.3(20.7-72.0)$ & $57.1(32.4-81.9)$ & $63.6(44.3-82.4)$ \\
\hline Self-inflating bag & $49.2(40.9-57.5)$ & $58.9(38.6-79.3)$ & $27.9(9.0-46.7)$ & $47.8(26.2-69.4)$ & $3.1(0.2-6.0)$ & $47.1(18.7-75.4)$ & $69.5(45.1-93.8)$ & $33.9(11.5-56.2)$ & $69.1(50.6-87.5)$ \\
\hline Flow-inflating bag & $49.4(41.1-57.7)$ & $44.6(24.3-65.0)$ & $52.6(31.3-73.8)$ & $53.3(31.7-74.9)$ & $38.5(7.8-69.3)$ & $64.0(36.6-81.4)$ & $36.8(12.4-61.2)$ & $70.7(48.5-92.8)$ & $39.9(20.6-59.2)$ \\
\hline $\begin{array}{l}\text { Ventilatory device } \\
\text { (self-inflating bag or } \\
\text { flow-inflating bag) }\end{array}$ & $82.7(76.3-89.1)$ & $86.7(72.4-100.0)$ & $74.4(55.5-93.2)$ & $83.2(67.4-99.9)$ & $41.7(10.7-72.7)$ & $77.9(53.4-100.0)$ & $81.0(59.6-100.0)$ & $100.0(77.4-100.0)$ & $91.7(84.9-100.0)$ \\
\hline Towels/Cloths & $29.5(22.0-36.9)$ & $43.3(23.0-63.6)$ & $32.6(12.5-52.7)$ & $19.8(3.5-36.1)$ & 0 & $8.8(3.1-14.6)$ & $15.8(0.0-32.2)$ & $36.1(12.2-60.0)$ & $44.5(24.8-64.2)$ \\
\hline Head covering & $12.3(7.2-17.4)$ & $22.9(6.0-39.8)$ & 0 & $6.0(3.0-9.0)$ & 0 & $2.9(0.4-5.5)$ & $15.8(0.0-32.2)$ & $18.0(0.0-37.2)$ & $19.9(4.4-35.5)$ \\
\hline
\end{tabular}


Table 3 Advanced equipment

\begin{tabular}{|c|c|c|c|c|c|c|c|c|c|}
\hline \multicolumn{2}{|l|}{ ESTIMATES } & \multicolumn{4}{|l|}{ Northern VN } & \multicolumn{4}{|l|}{ Southern VN } \\
\hline & Overall (n. 160) & Red (n. 27) & $\begin{array}{l}\text { North central } \\
\text { (n. 22) }\end{array}$ & North east (n. 26) & $\begin{array}{l}\text { North west } \\
\text { (n. 10) }\end{array}$ & $\begin{array}{l}\text { Central highlands } \\
\text { (n. 12) }\end{array}$ & $\begin{array}{l}\text { South central } \\
\text { (n. 16) }\end{array}$ & $\begin{array}{l}\text { South eastern } \\
\text { (n. 17) }\end{array}$ & Mekong (n. 30) \\
\hline Oxygen source & $100.0(100.0-100.0)$ & $100.0(100.0-100.0)$ & $100.0(100.0-100.0)$ & $\begin{array}{l}100.0(100.0- \\
100.0)\end{array}$ & $100.0(100.0-100.0)$ & $100.0(100.0-100.0)$ & $100.0(100.0-100.0)$ & $100.0(100.0-100.0)$ & $100.0(100.0-100.0)$ \\
\hline Laryngoscope & $62.8(54.6-70.9)$ & $16.6(5.3-27.9)$ & $59.6(38.7-80.4)$ & $40.9(20.1-61.6)$ & $20.8(0.0-45.2)$ & $89.0(70.3-100.0)$ & $71.6(47.2-95.9)$ & $91.7(77.5-100.0)$ & $100.0(100.0-100.0)$ \\
\hline Endotracheal tubes & $58.5(50.2-66.7)$ & $28.7(11.6-45.8)$ & $46.1(24.8-67.3)$ & $42.1(21.2-62.9)$ & $35.4(4.9-66.0)$ & $66.9(39.5-94.4)$ & $69.5(45.1-93.8)$ & $83.5(64.3-100.0)$ & $88.2(75.0-100.0)$ \\
\hline Infant warmer & $53.4(45.1-61.7)$ & $33.6(14.9-52.2)$ & $62.2(41.3-83.1)$ & $33.9(14.7-53.2)$ & $82.3(58.1-100.0)$ & $77.9(53.4-100.0)$ & $48.4(22.7-74.1)$ & $58.7(33.9-83.5)$ & $59.8(40.1-79.6)$ \\
\hline $\begin{array}{l}\text { Reservoir for ambu } \\
\text { bag }\end{array}$ & $53.1(44.8-61.4)$ & $43.4(23.1-63.8)$ & $35.3(15.2-55.4)$ & $15.2(2.8-27.7)$ & $17.7(0.0-41.9)$ & $75.0(50.5-99.5)$ & $78.9(57.6-100.0)$ & $68.7(33.9-83.5)$ & $86.4(73.3-99.6)$ \\
\hline Pulse oximeter & $9.4(5.2-13.6)$ & $8.4(0.0-19.0)$ & $1.3(0.3-2.9)$ & $21.0(4.6-37.4)$ & $3.1(0.2-6.0)$ & $11.0(0.0-29.7)$ & $2.1(0.3-3.9)$ & $12.9(0.0-27.2)$ & $10.7(0.9-20.5)$ \\
\hline Ventilator & $6.1(2.3-9.8)$ & $7.2(0.0-17.8)$ & $1.1(0.7-1.5)$ & $2.3(1.1-3.6)$ & $14.6(0.0-38.7)$ & 0 & $9.5(0.0-25.7)$ & $11.3(0.0-25.6)$ & $7.2(0.0-16.9)$ \\
\hline Laryngeal mask airway & $2.7(0.2-5.3)$ & $1.2(0.3-2.1)$ & 0 & 0 & $3.1(0.2-6.0)$ & $14.0(0.0-32.7)$ & $9.5(0.0-25.7)$ & $1.5(0.8-2.2)$ & 0 \\
\hline Polyethylene bags & $2.2(0.0-4.6)$ & $7.2(0.0-17.8)$ & 0 & $1.2(0.2-2.2)$ & 0 & 0 & 0 & $8.3(0.0-22.5)$ & 0 \\
\hline Room air source & $1.9(0.1-3.6)$ & $7.2(0.0-17.8)$ & 0 & 0 & $6.3(01.4-11.1)$ & 0 & $2.1(0.3-3.9)$ & $1.5(0.8-2.2)$ & 0 \\
\hline Blood gas analyzer & $1.2(0.0-3.1)$ & 0 & 0 & $1.1(0.7-1.6)$ & 0 & 0 & 0 & 0 & $5.5(0.0-15.1)$ \\
\hline
\end{tabular}

Data expressed as rate estimates $(95 \%$ C.I. $)$ 
regional estimates (with $95 \%$ Confidence Intervals) of available equipment were weighted to account for $100 \%$ sampling of central and provincial hospitals versus approximately $20 \%$ sampling of districts, and the exact sampling fractions were used for weighting. As the response rate was differential, regional data were also inflated by the inverse of the local response rate to ensure no systematic distortion of the estimated group parameters. Statistical analysis was performed using SAS v9.2 (SAS Institute Inc., Cary, NC, USA).

\section{Results}

The number of participants according to hospital level and administrative region is shown in Table 1. Overall, the response rate for the equipment section of the questionnaire was $85.7 \%$ (160/187 hospitals). The response rate was $84.4 \%$ (27/32) in Red River Delta, $88.0 \%(22 / 25)$ in North Central Coast, $86.7 \%(26 / 30)$ in Northeast, 100 \% (10/10) in Northwest, 80.0 \% (12/15) in Central Highlands, $72.7 \%(16 / 22)$ in South Central Coast, $94.4 \%(17 / 18)$ in Southeast and $85.7 \%(30 / 35)$ in Mekong River Delta. The estimates of equipment availability in each of the eight regions are reported in Table 2 (essential equipment) and Table 3 (advanced equipment).

Midwives were more frequently responsible for equipment preparation and check (Table 4). Overall, the availability of a written checklist was limited (Table 5).

\section{Discussion}

In this study, we assessed the equipment available for neonatal resuscitation in a large sample of Vietnamese delivery rooms, exploring regional differences. Our results show that a large proportion of the surveyed hospitals lack equipment classified as "essential" in the WHO and HBB algorithm. This problem was more marked in some regions than others. These data could be useful for guiding a program to supply and distribute material and equipment, to ensure that all birthing facilities in the country have the essential supplies.

In Vietnam, some of the essential equipment for neonatal resuscitation, such as scissors, suction devices, gloves, ties, ventilatory devices including self-inflating bag and flow-inflating bag, and face-masks was available in the majority of the hospitals. The availability of other relevant elements (stethoscope, clock, clothes and head covering) included in the $\mathrm{WHO}$ and $\mathrm{HBB}$ list were clearly insufficient. The lack of equipment was more marked in some administrative regions such as the Central Highlands and North west areas.

2010 AHA Guidelines for Neonatal Resuscitation recommend that heart rate should be detected with a stethoscope or electrocardiography because umbilical cord palpation is less accurate [14, 15]. Time registration is an important activity during neonatal resuscitation but, surprisingly, about half of the hospitals declared that a clock was not available in their delivery room [14-16]. Finally, prevention of thermal losses at birth is a crucial goal to reduce mortality and morbidity in neonates, especially preterm infants [17]. A combination of interventions such as environmental temperature at $23-25^{\circ} \mathrm{C}$, infant warmers, plastic bags, pre-warmed blankets and head covering is recommended to avoid hypothermia [14-16, 18, 19]. Notably, only $12.3 \%$ of hospitals reported the availability of a head covering for preventing neonatal hypothermia in delivery room while only $2.2 \%$ reported having a plastic bag. The effectiveness of a plastic bag on prevention of postnatal hypothermia in preterm infants has been demonstrated in high as well as low resource settings [20-23]. Implementation of these low-cost interventions in delivery room could significantly improve neonatal outcomes.

Turning to the list of "advanced" equipment, it is notable that only $9.4 \%$ of the Vietnamese hospitals have a pulse oximeter in the delivery room. 2010 Guidelines for Neonatal Resuscitation state that "It is recommended that oximetry be used when resuscitation can be anticipated, when positive pressure is administered for more than a few breaths, when cyanosis is persistent, or when supplementary oxygen is administered" [15]. The inability to titrate oxygen supplementation guided by an oximeter may expose neonates to high oxygen concentrations and, consequently, increase mortality [24]. In addition, the availability of a room air

Table 4 Health caregiver responsible for equipment check

\begin{tabular}{|c|c|c|c|c|c|c|c|c|c|}
\hline \multicolumn{2}{|c|}{ ESTIMATES } & \multicolumn{4}{|c|}{ Northern VN } & \multicolumn{4}{|l|}{ Southern VN } \\
\hline & $\begin{array}{l}\text { Overall } \\
\text { (n. 160) }\end{array}$ & $\begin{array}{l}\text { Red } \\
\text { (n. 27) }\end{array}$ & $\begin{array}{l}\text { North central } \\
\text { (n. 22) }\end{array}$ & $\begin{array}{l}\text { North east } \\
\text { (n. 26) }\end{array}$ & $\begin{array}{l}\text { North west } \\
\text { (n. 10) }\end{array}$ & $\begin{array}{l}\text { Central highlands } \\
\text { (n. 12) }\end{array}$ & $\begin{array}{l}\text { South central } \\
\text { (n. 16) }\end{array}$ & $\begin{array}{l}\text { South eastern } \\
\text { (n. 17) }\end{array}$ & $\begin{array}{l}\text { Mekong } \\
\text { (n. 30) }\end{array}$ \\
\hline Midwife & $\begin{array}{l}83.2 \\
(76.9-89.4)\end{array}$ & $\begin{array}{l}84.3 \\
(69.9-98.7)\end{array}$ & $\begin{array}{l}74.4 \\
(55.5-93.2)\end{array}$ & $\begin{array}{l}83.7 \\
(67.5-100.0)\end{array}$ & $\begin{array}{l}70.8 \\
(40.2-100.0)\end{array}$ & $\begin{array}{l}77.9 \\
(53.4-100.0)\end{array}$ & $\begin{array}{l}78.9 \\
(57.5-100.0)\end{array}$ & $\begin{array}{l}97.0 \\
(94.6-99.0)\end{array}$ & $\begin{array}{l}89.0 \\
(75.9-100.0)\end{array}$ \\
\hline Physician & $\begin{array}{l}18.5 \\
(12.0-25.1)\end{array}$ & $\begin{array}{l}20.5 \\
(3.7-37.4)\end{array}$ & $\begin{array}{l}24.3 \\
(5.5-43.1)\end{array}$ & $\begin{array}{l}31.4 \\
(10.8-51.9)\end{array}$ & $\begin{array}{l}17.7 \\
(0.0-41.9)\end{array}$ & $\begin{array}{l}11.0 \\
(0.0-29.7)\end{array}$ & $\begin{array}{l}19.0 \\
(0.0-40.4)\end{array}$ & $\begin{array}{l}1.5 \\
(0.3-2.8)\end{array}$ & $\begin{array}{l}15.3 \\
(2.1-28.5)\end{array}$ \\
\hline Nurse & $\begin{array}{l}8.6 \\
(4.1-13.0)\end{array}$ & $\begin{array}{l}1.2 \\
(0.3-2.2)\end{array}$ & $\begin{array}{l}13.5 \\
(0.0-28.0)\end{array}$ & $\begin{array}{l}15.1 \\
(0.0-31.3)\end{array}$ & 0 & $\begin{array}{l}27.9 \\
(3.4-52.5)\end{array}$ & $\begin{array}{l}13.7 \\
(0.0-30.0)\end{array}$ & $\begin{array}{l}3.0 \\
(1.0-5.0)\end{array}$ & 0 \\
\hline
\end{tabular}

Data expressed as rate estimates (95\% C.I.) 
Table 5 Availability of written checklist

\begin{tabular}{|c|c|c|c|c|c|c|c|c|c|}
\hline \multicolumn{2}{|l|}{ ESTIMATES } & \multicolumn{4}{|c|}{ Northern VN } & \multicolumn{4}{|l|}{ Southern VN } \\
\hline & $\begin{array}{l}\text { Overall } \\
\text { (n. 160) }\end{array}$ & $\begin{array}{l}\text { Red } \\
\text { (n. 27) }\end{array}$ & $\begin{array}{l}\text { North central } \\
\text { (n. 22) }\end{array}$ & $\begin{array}{l}\text { North east } \\
\text { (n. 26) }\end{array}$ & $\begin{array}{l}\text { North west } \\
\text { (n. 10) }\end{array}$ & $\begin{array}{l}\text { Central highlands } \\
\text { (n. 16) }\end{array}$ & $\begin{array}{l}\text { South central } \\
\text { (n. 16) }\end{array}$ & $\begin{array}{l}\text { South eastern } \\
\text { (n. 17) }\end{array}$ & $\begin{array}{l}\text { Mekong } \\
\text { (n. 30) }\end{array}$ \\
\hline $\begin{array}{l}\text { Availability of } \\
\text { written checklist }\end{array}$ & $\begin{array}{l}39.4 \\
(31.3-47.4)\end{array}$ & $\begin{array}{l}59.2 \\
(39.4-79.0)\end{array}$ & $\begin{array}{l}28.1 \\
(9.2-46.9)\end{array}$ & $\begin{array}{l}20.0 \\
(6.9-33.1)\end{array}$ & $\begin{array}{l}6.3 \\
(1.4-11.1)\end{array}$ & $\begin{array}{l}47.1 \\
(18.7-75.4)\end{array}$ & $\begin{array}{l}44.2 \\
(18.6-69.8)\end{array}$ & $\begin{array}{l}30.9 \\
(8.7-53.0)\end{array}$ & $\begin{array}{l}54.3 \\
(34.4-74.2)\end{array}$ \\
\hline
\end{tabular}

Data expressed as rate estimates (95\% C.I.)

source to allow blending was very limited (1.9\% of the sample); this could be a serious problem because the initial oxygen concentrations for preterm infants ( $<35$ weeks gestation) should be $21-30 \%$ [16]. In these circumstances, a scheme correlating the oxygen flow rate and the corresponding delivered oxygen concentrations when using a neonatal self inflating bag can be used $[25,26]$. Although the availability of written checklists for equipment and material preparation is an important organizational issue [14-16], they were routinely used in only $39.4 \%$ of surveyed centers. This is another important aspect that needs to be improved.

Similar national or local surveys have been previously conducted in high [27-29] as well in low resource settings $[30,31]$. These studies aimed to assess the practices of health caregivers and their adherence to official guidelines more than the availability of equipment [27-29]. Also these studies showed marked variation among the hospitals and/or the regional areas within the same country [13, 27-31].

A recent study examined progress in the implementation of the basic emergency obstetric and neonatal care (EmONC) in Addis Ababa comparing two periods: 2008 (before the intervention) and 2013 (after the intervention) [31]. The results show that there were advances in infrastructure, medical supplies and personnel for EmONC provision. However, providers knowledge scores on diagnosis and management of labor, bleeding after childbirth, birth asphyxia and skill scores on neonatal resuscitation did not improved between the two periods suggesting that, in addition to infrastructure and medical equipment, staff education remains a key point for improving the quality of maternal and neonatal care [27-31].

As the relationship between the quality of health providers' practice and the availability of adequate equipment has been previously demonstrated [1, 32], the results of this study should be interpreted together with the data obtained from our previous survey [13]. This approach will help to obtain an objective picture of the regional areas that need more educational and technical investments.

The strength of this study is national representation and the high response rate $(85.6 \%)$ of the enrolled hospitals, with good representation of all administrative regions. However, there are some limitations to this study. We involved only the directors of the participating centres and relied on self-report, without inspection of the sites and observation of clinical practices. The sampling strategy give us confidence in the accuracy of the national estimates, but the response rate, while high at $85.7 \%$ overall, leaves open the possibility of selection biases if responding hospitals have higher or lower rates of equipment availability than non-respondents. As the survey was conducted in 2012 and based on 2011 practice, changes may have already occurred during the last 5 years.

\section{Conclusion}

Our study reports on the equipment available for neonatal resuscitation in a large representative sample of Vietnamese hospitals. Our results show that the equipment classified as "essential" by the WHO guidelines and HBB algorithm was not available in a considerable portion of the surveyed hospitals. This problem was more relevant in some regions. Our data could provide a basis for ensuring that all Vietnamese hospitals that offer maternity services have a full complement of essential and advanced resuscitation equipment. The assessment strategy used in this study could be replicated as a basis for organizing the supply and distribution of material and equipment in other low and/or middle resource settings.

\section{Abbreviations}

AAP, American Academy of Pediatrics; AHA, American Heart Association; DR; delivery room; HBB, helping babies breathe; WHO, World Health Organization

\section{Acknowledgements}

We would like to thank the heads of the participating centres for their assistance with this survey.

The research was conducted within a development program implemented by the non-governamental organization Amici della Neonatologia Trentina (Trento, Italy), in partnership with Thrive Networks (Oakland, California, USA), with the financial support of the Autonomous Province of Trento, Italy.

\section{Funding}

The funding for the project described in this study was provided in a fund matching agreement between three partners: the Archdioceses of Trento, Italy, and the Autonomous Province of Trento, Italy; donors to Amici della Neonatologia Trentina, an international non-governmental organization headquartered in Trento, Italy; and donors to Thrive Networks, an international non-governmental organization headquartered in Oakland, California, USA

\section{Availability of data and materials}

The datasets generated during and/or analyzed during the current study are not publicly available to protect participating hospitals confidentiality, but are available from the corresponding author (DT) on reasonable request. 


\section{Authors' contributions}

DT conceived and designed the study. He drafted the initial manuscript, revised it for important intellectual content, and approved the final manuscript as submitted. FC and GA designed the study, carried out the analyses, contributed to interpretation of data, revised the manuscript and approved the final manuscript as submitted. TDC and OL prepared the questionnaire and sent it to the Centres, contributed to interpretation of data, revised the manuscript and approved the final manuscript as submitted. NMX, NVT, NTXH designed the data collection instruments, contributed to data collection at the sites, contributed to interpretation of data, critically reviewed the manuscript, and approved the final manuscript as submitted. LM conceived the study, revised the manuscript for important intellectual content, and approved the final manuscript as submitted.

\section{Competing interests}

The authors declare that they have no competing interest.

\section{Consent for publication}

Consent from Directors of participating hospitals was obtained for this study, which included consent for publication without any identifying hospital information.

\section{Ethics approval and consent to participate}

This study did not include human or clinical data and/or patients' information but only data on the availability of equipment in the participating hospitals. Therefore, according to the declaration of Helsinki, ethics approval is not required.

\section{Author details}

'Women's and Children's Health Department, Medical School, University of Padua, Azienda Ospedaliera di Padova, Via Giustiniani, 3, 35128 Padua, Italy. ${ }^{2}$ Amici della Neonatologia Trentina (ANT), Trento, Italy. ${ }^{3}$ Independent statistician, Padua, Italy. ${ }^{4}$ Thrive Networks, Oakland, CA, USA. ${ }^{5}$ School of Public Health \& Community Medicine, Faculty of Medicine, University of New South Wales, Sydney, NSW, Australia. ${ }^{6}$ World Health Organization, Country Office Bhutan, Thimphu, Bhutan. ${ }^{7}$ University of Medicine Pham Ngoc Thach, Ho Chi Minh City, Vietnam. ${ }^{8}$ Perinatal and Neonatal Association of Ho Chi Minh City, Ho Chi Minh City, Vietnam. ${ }^{9}$ National Hospital of Obstetrics and Gynecology, Hanoi, Vietnam.

\section{Received: 29 April 2016 Accepted: 5 August 2016}

\section{Published online: 20 August 2016}

\section{References}

1. Lawn JE, Blencowe H, Oza S, You D, Lee AC, Waiswa P, Lalli M, Bhutta Z, Barros AJ, Christian P, Mathers C, Cousens SN, Lancet Every Newborn Study Group. Every newborn: progress, priorities, and potential beyond survival. Lancet. 2014;384(9938):189-205.

2. Wall SN, Lee ACC, Niermeyer S, et al. Neonatal resuscitation in low-resource settings: what, who, and how to overcome challenges to scale up? Int J Gynaecol Obstet. 2009;107(suppl):S47-64.

3. World Health Organization: Early Essential Newborn Care. Pocket guide. WHO Western Pacific Regional Office, 2014. http://iris.wpro.who.int/ bitstream/handle/10665.1/10798/9789290616856_eng.pdf; jsessionid=D0C09F6A0908E8CC22B8DBC56D6E3240? sequence=3. Accessed 9 Aug 2016

4. AAP Guide for Implementation of HBB". http://www.helpingbabiesbreathe. org/docs/IG_pdfs/lmpl.\%20guide\%2022\%20december\%202011.pdf. Accessed 9 Aug 2016

5. UNICEF. The State of the World's Children 2015. http://www.unicef.org/sowc/. Accessed 9 Aug 2016

6. Nga NT, Hoa DT, Malqvist M, Persson LA, Ewald U. Causes of neonatal death: results from NeoKIP community-based trial in Quang Ninh province, Vietnam. Acta Paediatr. 2012;101(4):368-73.

7. Wallin L, Malqvist M, Nga NT, et al. Implementing knowledge into practice for improved neonatal survival; a cluster-randomised, community-based trial in Quang Ninh province, Vietnam. BMC Health Serv Res. 2011;11:239.

8. United Nations Vietnam. Achieving the MDGs with Equity, 2012. www.un. org.vn/en.html. Accessed 9 Aug 2016

9. Committee for Population, Family and Children. Vietnam Demographic and Health Survey 2002. Hanoi, Calverton: ORC Macro; 2003.
10. Save the Children. A Situational Analysis of Newborn Health and Interventions in Vietnam: Towards the Development of a Newborn Health Action Plan, 2006. USA.

11. Ministry of Health - Vietnam. National Plan of Action for Child Survival 2009-2015. Hanoi, Vietnam: Ministry of Health; 2009.

12. Ministry of Health - Vietnam. National Clinical Guidelines on Reproductive Health Care Services. Hanoi, Vietnam: Ministry of Health; 2003.

13. Trevisanuto D, Marchetto L, Arnolda G, Chien TD, Lincetto O, Cavallin F, Xuan NM, Tien NV, Hoi NT, Moccia L. Neonatal resuscitation in Vietnam: a national survey of a middle-income country. Acta Paediatr. 2015;104(6):e255-62.

14. Perlman JM, Wyllie J, Kattwinkel J, Atkins DL, Chameides L, Goldsmith JP, Guinsburg R, Hazinski MF, Morley C, Richmond S, Simon WM, Singhal N, Szyld E, Tamura M, Velaphi S, Neonatal Resuscitation Chapter Collaborators. Part 11: Neonatal resuscitation: 2010 International Consensus on Cardiopulmonary Resuscitation and Emergency Cardiovascular Care Science With Treatment Recommendations. Circulation. 2010;122(16 Suppl 2):S516-38.

15. Kattwinkel J, Perlman JM, Aziz K, Colby C, Fairchild K, Gallagher J, Hazinski MF, Halamek LP, Kumar P, Little G, McGowan JE, Nightengale B, Ramirez MM, Ringer S, Simon WM, Weiner GM, Wyckoff M, Zaichkin J, American Heart Association. Neonatal resuscitation: 2010 American Heart Association guidelines for cardiopulmonary resuscitation and emergency cardiovascular care. Pediatrics. 2010;126:e1400-13.

16. Wyllie J, Bruinenberg J, Roehr CC, Rüdiger M, Trevisanuto D, Urlesberger B. European Resuscitation Council Guidelines for Resuscitation 2015: Section 7. Resuscitation and support of transition of babies at birth. Resuscitation. 2015;95:249-63.

17. Lyu Y, Shah PS, Ye XY, Warre R, Piedboeuf B, Deshpandey A, Dunn M, Lee SK, Canadian Neonatal Network. Association between admission temperature and mortality and major morbidity in preterm infants born at fewer than 33 weeks' gestation. JAMA Pediatr. 2015;169(4):e150277.

18. Perlman JM, Wyllie J, Kattwinkel J, Wyckoff MH, Aziz K, Guinsburg R, Kim HS, Liley HG, Mildenhall L, Simon WM, Szyld E, Tamura M, Velaphi S, Neonatal Resuscitation Chapter Collaborators. Part 7: Neonatal Resuscitation: 2015 International Consensus on Cardiopulmonary Resuscitation and Emergency Cardiovascular Care Science With Treatment Recommendations. Circulation. 2015;132(16 Suppl 1):S204-41.

19. McCall EM, Alderdice FA, Halliday HL, Jenkins JG, Vohra S. Interventions to prevent hypothermia at birth in preterm and/or low birthweight infants. Cochrane Database Syst Rev. 2010;3, CD004210.

20. Vohra S, Roberts RS, Zhang B, Janes M, Schmidt B. Heat Loss Prevention (HeLP) in the delivery room: a randomized controlled trial of polyethylene occlusive skin wrapping in very preterm infants. J Pediatr. 2004;145(6):750-3.

21. Trevisanuto D, Doglioni N, Cavallin F, Parotto M, Micaglio M, Zanardo V. Heat loss prevention in very preterm infants in delivery rooms: a prospective, randomized, controlled trial of polyethylene caps. J Pediatr. 2010;156(6):914-7. 917.e1.

22. Belsches TC, Tilly AE, Miller TR, Kambeyanda RH, Leadford A, Manasyan A, Chomba E, Ramani M, Ambalavanan N, Carlo WA. Randomized trial of plastic bags to prevent term neonatal hypothermia in a resource-poor setting. Pediatrics. 2013;132(3):e656-61.

23. Leadford AE, Warren JB, Manasyan A, Chomba E, Salas AA, Schelonka R Carlo WA. Plastic bags for prevention of hypothermia in preterm and low birth weight infants. Pediatrics. 2013;132(1):e128-34.

24. Saugstad OD. Resuscitation of newborn infants: from oxygen to room air. Lancet. 2010;376(9757):1970-1.

25. Trevisanuto D, Dal Cengio V, Doglioni N, Cavallin F, Zanardo V, Parotto M, Weiner G. Oxygen delivery using a neonatal self-inflating resuscitation bag: effect of oxygen flow. Pediatrics. 2013;131:e1144-9.

26. Thio M, van Kempen L, Rafferty AR, Bhatia R, Dawson JA, Davis PG. Neonatal resuscitation in resource-limited settings: titrating oxygen delivery without an oxygen blender. J Pediatr. 2014;165(2):256-60.e1.

27. El-Naggar W, McNamara PJ. Delivery room resuscitation of preterm infants in Canada: current practice and views of neonatologists at level III centers. J Perinatol. 2012;32(7):491-7.

28. Singh $\mathrm{Y}$, Oddie $\mathrm{S}$. Marked variation in delivery room management in very preterm infants. Resuscitation. 2013;84(11):1558-61.

29. Trevisanuto D, Satariano I, Doglioni N, Criscoli G, Cavallin F, Gizzi C, Martano C, Ciralli F, Torielli F, Villani PE, Di Fabio S, Quartulli L, Giannini L, Neonatal Resuscitation Study Group, Italian Society of Neonatology. Changes over time in delivery room management of extremely low birth weight infants in Italy. Resuscitation. 2014;85(8):1072-6. 
30. Owens L, Semrau K, Mbewe R, Musokotwane K, Grogan C, Maine D, Hamer $\mathrm{DH}$. The state of routine and emergency obstetric and neonatal care in Southern Province, Zambia. Int J Gynaecol Obstet. 2015;128(1):53-7.

31. Mirkuzie AH, Sisay MM, Reta AT, Bedane MM. Current evidence on basic emergency obstetric and newborn care services in Addis Ababa, Ethiopia; a cross sectional study. BMC Pregnancy Childbirth. 2014;14:354.

32. Trevisanuto D, Raggi R, Bavuusuren B, Tudevdorj E, Doglioni N, Zanardo V. Investments for medical equipment in a mother and child health hospital: correlation with level of services/departments. J Matern Fetal Neonatal Med. 2011;24(2):234-8.

Submit your next manuscript to BioMed Central and we will help you at every step:

- We accept pre-submission inquiries

- Our selector tool helps you to find the most relevant journal

- We provide round the clock customer support

- Convenient online submission

- Thorough peer review

- Inclusion in PubMed and all major indexing services

- Maximum visibility for your research

Submit your manuscript at www.biomedcentral.com/submit
Biomed Central 